IJIET, e-ISSN 2548-8430, p-ISSN 2548-8422, Vol. 1, No. 1, January 2017

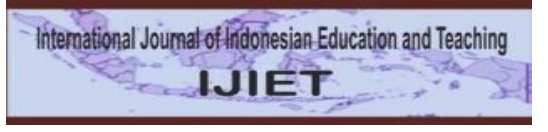

International Journal of Indonesian Education and Teaching

http://e-journal.usd.ac.id/index.php/IJIET

Sanata Dharma University, Yogyakarta, Indonesia

\title{
MATHEMATICAL LITERACY PROFILE OF GRADE VIII STUDENTS OF SMP PANGUDI LUHUR 1 YOGYAKARTA USING PENDIDIKAN MATEMATIKA REALISTIK INDONESIA APPROACH
}

\author{
Stephani Rangga Larasati and Veronika Fitri Rianasari \\ Mathematics Education of Sanata Dharma University \\ stephanirangga@gmail.com and veronikafitri@usd.ac.id \\ https://doi.org/10.24071/ijiet.v1i1.326
}

\begin{abstract}
This research aims to investigate mathematical literacy of students grade VIII SMP Pangudi Luhur 1 Yogyakarta before and after learning using the Pendidikan Matematika Realistik Indonesia (PMRI) approach. This research was a descriptive qualitative research. The research subjects were 36 students of class VIII-F, SMP Pangudi Luhur 1 Yogyakarta. This research was conducted in March until July of 2016. The data was collected through observation, instructional video recording, and the results of pretest and posttest. Pretest and posttest was designed based on the characteristics of PISA (Program for International Student Assessment) problem. Instructional video was analyzed in qualitative with making a transcript of the video, determining topics of the data, and categorizing the data. The results of pretest and posttest were analyzed qualitatively to determine the students' ability of mathematical literacy. The findings showed that before the implementation of PMRI the students get a better result in solving PISA problem level 2 compared with the result in solving PISA problem level 3, but after the implementation of PMRI the students get a better result in solving PISA problem level 3 compared with the result in solving PISA problem level 2. It is affected by PMRI learning which applied more focused to guide students to construct their mathematical knowledge instead of doing routine exercises of solving PISA problems.
\end{abstract}

Keywords: Mathematical Literacy, Cube, Cuboid, PMRI

\section{Introduction}

Education is one of things that affect the quality of human resources. As formulated in the preamble of 1945 Constitution and supported by Law No. 20 Year 2003 about National Education System in Article 3, education in Indonesia have goals that support qualified human resources. Therefore, a good quality education is one of the factors creating a good quality of human resources as well.

Effort to improve the quality of education at all levels of primary and secondary school is performed in all groups of subjects contained in the content standard (UNIMED, 2012). One of the discipline that can improve the quality of education is mathematics.

Mathematics is one of the subjects that must be learned in every level of education, starting from Elementary School, Junior High School, and Senior High 
School. The reason is that mathematics is a universal science that underlies the development of modern technology. It has an important role in variety of disciplines and advances the power of human thoughts. According to NCTM (2000), in studying mathematics, students are required to have the capability of understanding the problem solving, communication, and mathematical connection.

The content standard of mathematics subject is contained in PERMENDIKNAS No. 22 Year 2006 states that the objective of mathematics subject is that students have the ability to understand mathematical concepts, using reasoning, problem solving, communicating ideas, and having a respect for the use of mathematics in life.

The purpose of mathematics education in primary and secondary schools above is in accordance with aspects of mathematical literacy. Mathematical literacy is ability of individual to formulate, use, and interprets mathematics in various contexts, including ability to perform reasoning mathematically and using concept, procedure, and fact as tool to describe, explain, and predict a phenomenon or event (OECD, 2003).

Mathematical literacy is very important for everyone associated with work and activity in daily life. Mathematical literacy is needed, not only the limitationof arithmetic understanding, but also require mathematical reasoning and problem solving, as well as control of logical reasoning to solve problems in daily life.

Thus, mathematical literacy is skill that should be owned by a person in order to be able to face all the problems that faced in daily life. However, basedon several research projects worldwide, followed by Indonesia, one of them is PISA (Program for International Student Assessment) still shows unsatisfactory results. PISA is an international level study conducted by the Organization for Economic Cooperation and Development (OECD). PISA aims to assess what extent students study at the end of primary school (students aged 15) has masterednecessary knowledge and skills to be able to participate as citizens or community members who build and responsible (Sugandi, 2013: 2). The assessment of PISA includes mathematical literacy, reading literacy, and scientific literacy.

Indonesia mathematical literacy in PISA 2000, 2003, 2006, and 2009 successively occupy the seventh position from the bottom (Balitbang, 2011). Although, in PISA 2012 which puts mathematics as the main focus, Indonesia was ranked 64 of 65 countries with an average score 375, while the average of international score is 494 (The Guadian, 2013).

One of factors causing the students' low ability of mathematical literacy is students unusual to face questions that have substance contextual, demanding reasoning, argumentation, and creativity in finishing the questions (Balitbang, 2011). SMP Pangudi Luhur 1 is a private featured school in Yogyakarta. Based on the observation of syllabus and lesson plan which were designed by mathematics teacher at SMP PangudiLuhur 1, the syllabus is generally presents an instrument of learning which is substantially less associated with the context in daily life and less facilitate students in revealing the thinking process and giving argument. Also, based on the interview's results from some students, they have difficulties in understanding and preparing steps to resolve when the researcher gave story 
questions related to cube and cuboid, in contrast, when the researcher gave a question clearly and directly without requiring reasoning toward the question.

Based on the above exposure should be improved upon learning of mathematics, especially things that related to mathematical literacy. Related to effort to improve mathematical literacy, the government is working with several universities in Indonesia that held a Kontes Literasi Matematika (KLM) which one of them was held at Sanata Dharma University, Yogyakarta. One of schools that participating in KLM held at Sanata Dharma University is SMP Pangudi Luhur 1 Yogyakarta. SMP Pangudi Luhur 1 Yogyakarta has followed KLM at Sanata Dharma University for 3 years consecutively in 2013, 2014, and 2015, but it is still not showing maximum results.

One model of learning mathematics that can lead to a positive impact on students' ability of mathematical literacy in problem solving is Model Pembelajaran Pendidikan Matematika Realistik Indonesia (PMRI) (Santika, dkk: 2012). The excellence PMRI as proposed by Wijaya (2012:20) is emphasizing "learning by doing", in accordance with the basic concepts of mathematics learning realistic expressed Freudental (Van Den Heuvel-Panhuizenthe: 1998) that "mathematics as a human activity" which means mathematics as a human activity where math is actually familiar with daily life activities. PMRI in measuring the students' ability is to use questions or problems that can be lifted from variety of situations, so it becomes a source of learning. This is consistent with how to measure the students' ability in PISA test. The assessment of PISA uses questions relating to real life. PISA refers to philosophy, mathematics is not an isolated science of human life, but it appears and useful in daily life (Wijaya, 2012: 2). It is related to what has been expressed by Marpaung and Hongki (2011) that in PMRI, learning as much as possible starting with presenting contextual/realistic problems. In PISA test is intended to see the students' ability to use mathematics that learned to solve the problems related to life (contextual). In PMRI, teachers give students opportunity to solve the problems in their own way while the objective of PISA assessment is to provide feedback on mathematics learning in schools. Some mathematical competences in PISA can be seen in Table 1.

Table 1. Levels 2 and 3 in PISA (OECD, 2010)

\begin{tabular}{|l|l|}
\hline Level & \multicolumn{1}{|c|}{ Mathematic Competence } \\
\hline 2 & $\begin{array}{l}\text { At level 2 students can intepret and recognize situations in context that } \\
\text { require no more than direct inference. They can extract relevant } \\
\text { information from a single source and make use of a single } \\
\text { representational mode. Student at this level can employ basic algorithms, } \\
\text { formulae, procedures, or conventions. They are capable of direct } \\
\text { reasoning and making literal interpretations of the result. }\end{array}$ \\
\hline
\end{tabular}


\begin{tabular}{|l|l|}
\hline 3 & $\begin{array}{l}\text { At level } 3 \text { students can execute clearly described procedures, including } \\
\text { those that require sequential decisions. They can select and apply simple } \\
\text { problem-solving strategis. Students at this level can intepret and use } \\
\text { representation based on different information sources and reason directly } \\
\text { from them. They can develop short communication reporting } \\
\text { ther interpretation, result and reasoning. }\end{array}$ \\
\hline
\end{tabular}

Therefore, learning using PMRI has close relationship with the students' mathematical literacy. PMRI learning implementation is expected to facilitate students to formulate, use and interpret mathematics in various contexts, including the ability to perform reasoning mathematically and using the concept, procedure, and fact as tool to describe, explain, and predict a phenomenon or event. Therefore, the implementation of PMRI learning can develop the components of the students and can support the students' ability of mathematical literacy itself.

From several reasons that already mentioned, PMRI is appropriate to use as one of approaches in effort to improve students' mathematical literacy. Based on the data and consideration above, it is necessary to research which examines students' mathematical literacy in learning using PMRI approach. This research is coupled with the title "Profile of Students' Ability of Mathematical Literacy Grade VIIIF SMP Pangudi Luhur 1 Yogyakarta in Learning Using PMRI (Pendidikan Matematika Realistik Indonesia) Approach, Subjects of Cube and Cuboid in Academic Year 2015/2016".

\section{Method}

The methodology of this research is descriptive qualitative approach with quantitative assisted. Descriptive research with quantitative approach is a study that aims to describe phenomena in real, where these phenomena are described based on the calculation of amount, size, or frequency (Nana Sukmadinata, 2012).

This research was conducted in SMP Pangudi Luhur 1 Yogyakarta in

Academic Year 2015/2016 in class VIIIF. The data used in this research is students' answer sheet of pretest and posttest results. The data collection was conducted through pretest and posttest. There are 6 levels in mathematical competence in PISA, but in this research, the researcher focused on students' ability of mathematical literacy in finishing level 2 and level 3. Pretest consists of 3 questions where the question number 1 and number 2 are questions of level 2 and question number 3 is question of level 3. Posttest consists of type A and type B where question number 1 and number 2 are questions of level 2 and question number 3 and number 4 are questions of level 3.

\section{Results and Discussion}

Implementation of Learning Using PMRI Approach

The course always begins with greeting, delivering learning objectives and plan activities to be carried out, and then the teacher continues with the provision of context, so students can understand and imagine the materials that will be studied. Besides, giving context also shows the benefits of learning the material, so the students will be more motivated. The next activity was teacher gives 
students questions to be solved with students' ability that they have already learned and their prior knowledge. From problem solving activities, the students got a model completion from students' construction; the model is called "model of". Then, the teacher improvised questions with a higher difficulty and the students solve the questions by developing a model that they have mastered previously, this model is called "model for". Learning using PMRI approach uses students' contribution especially in exploring idea of completion. The teacher stimulates students' knowledge to solve a problem through guided questions. In the process, the teacher facilitates better interaction and negotiation between teacher-student and even among students. Negotiation between teacher and student is done with active teacher around the classroom when group is working, while the interaction and negotiation among students are applied when the teacher gives questions from a student to another, or by asking if there is a different solution when a group presents their work. Another feature of learning using PMRI approach is the relation between mathematical concept with one another and linkages with material beyond mathematics. The teacher has linked mathematical concepts with other mathematical concepts, but the teacher has not been able to associate the material with other materials beyond mathematics.

\section{Students' Mathematical Literacy}

Here are the percentages of many students in each indicator of students' mathematical literacy:

Table 2. Percentage of Many Students in Each Indicator of Students' Mathematical Literacy Pretest Number 1 (Level 2)

\begin{tabular}{|l|l|l|l|}
\hline $\begin{array}{l}\text { Mathematical } \\
\text { Literacy Ability }\end{array}$ & $\mathrm{A}$ & $\mathrm{n}$ & $\mathrm{P}$ \\
\hline R1 & 11 & 36 & $30.55 \%$ \\
\hline R2 & 9 & 36 & $25 \%$ \\
\hline R3 & 3 & 36 & $8.33 \%$ \\
\hline R4 & 8 & 36 & $22.22 \%$ \\
\hline R5 & 3 & 36 & $8.33 \%$ \\
\hline TR & 2 & 36 & $5.55 \%$ \\
\hline
\end{tabular}

Table 3. Percentage of Many Students in Each Indicator of Students' Ability of Mathematical Literacy Pretest Number 2 (Level 2)

\begin{tabular}{|l|l|l|l|}
\hline $\begin{array}{l}\text { Mathematical } \\
\text { Literacy Ability }\end{array}$ & $\mathrm{A}$ & $\mathrm{n}$ & $\mathrm{P}$ \\
\hline R1 & 11 & 36 & $30.55 \%$ \\
\hline R2 & 14 & 36 & $38.88 \%$ \\
\hline R3 & 0 & 36 & $0 \%$ \\
\hline R4 & 6 & 36 & $16.66 \%$ \\
\hline R5 & 5 & 36 & $13.88 \%$ \\
\hline TR & 0 & 36 & $0 \%$ \\
\hline
\end{tabular}


Table 4. Percentage of Many Students in Each Indicator of Students' Mathematical Literacy Pretest Number 3 (Level 3)

\begin{tabular}{|l|l|l|l|}
\hline $\begin{array}{l}\text { Mathematical } \\
\text { Literacy Ability }\end{array}$ & $\mathrm{A}$ & $\mathrm{n}$ & $\mathrm{P}$ \\
\hline R1 & 4 & 36 & $11.11 \%$ \\
\hline R2 & 3 & 36 & $8.33 \%$ \\
\hline R3 & 4 & 36 & $11.11 \%$ \\
\hline R4 & 13 & 36 & $36.11 \%$ \\
\hline R5 & 10 & 36 & $27.77 \%$ \\
\hline TR & 2 & 36 & $5.55 \%$ \\
\hline
\end{tabular}

Table 5. Percentage of Many Students in Each Indicator of Students' Mathematical Literacy Posttest Number 1 (Level 2)

\begin{tabular}{|c|c|c|c|c|c|c|}
\hline \multirow{2}{*}{$\begin{array}{l}\text { Mathematical } \\
\text { Literacy } \\
\text { Ability }\end{array}$} & \multicolumn{3}{|c|}{ Tipe A } & \multicolumn{3}{|c|}{ Tipe B } \\
\hline & A & $n_{A}$ & $\mathrm{P}$ & A & $n_{B}$ & $\mathrm{P}$ \\
\hline R1 & 2 & 18 & $11.11 \%$ & 3 & 18 & $16.66 \%$ \\
\hline R2 & 1 & 18 & $5, .55 \%$ & 5 & 18 & $27.77 \%$ \\
\hline R3 & 3 & 18 & $16.66 \%$ & 0 & 18 & $0 \%$ \\
\hline $\mathrm{R} 4$ & 2 & 18 & $11.11 \%$ & 2 & 18 & $11.11 \%$ \\
\hline R5 & 3 & 18 & $16.66 \%$ & 2 & 18 & $11.11 \%$ \\
\hline TR & 7 & 18 & $38.88 \%$ & 6 & 18 & $33.33 \%$ \\
\hline
\end{tabular}

Table 6. Percentage of Many Students in Each Indicator of Students' Mathematical Literacy Posttest Number 2 (Level 2)

\begin{tabular}{|l|l|l|l|}
\hline $\begin{array}{l}\text { Mathematical } \\
\text { Literacy Ability }\end{array}$ & A & n & P \\
\hline R1 & 5 & 36 & $13.88 \%$ \\
\hline R2 & 1 & 36 & $2.77 \%$ \\
\hline R3 & 8 & 36 & $22.22 \%$ \\
\hline R4 & 8 & 36 & $22.22 \%$ \\
\hline R5 & 0 & 36 & $0 \%$ \\
\hline TR & 14 & 36 & $38.88 \%$ \\
\hline
\end{tabular}


Table 7. Percentage of Many Students in Each Indicator of Students' Mathematical Literacy Posttest Number 3 (Level 3)

\begin{tabular}{|c|c|c|c|c|c|c|}
\hline \multirow{2}{*}{$\begin{array}{l}\text { Mathematical } \\
\text { Literacy } \\
\text { Ability }\end{array}$} & \multicolumn{3}{|c|}{ Tipe A } & \multicolumn{3}{|c|}{ Tipe B } \\
\hline & A & $\mathrm{n}_{\mathrm{a}}$ & $\mathrm{P}$ & A & $\mathrm{n}_{\mathrm{b}}$ & $\mathrm{P}$ \\
\hline R1 & 1 & 18 & $5.55 \%$ & 2 & 18 & $11.11 \%$ \\
\hline $\mathrm{R} 2$ & 5 & 18 & $27.77 \%$ & 4 & 18 & $22.22 \%$ \\
\hline $\mathrm{R} 3$ & 1 & 18 & $5.55 \%$ & 2 & 18 & $11.11 \%$ \\
\hline $\mathrm{R} 4$ & 0 & 18 & $0 \%$ & 0 & 18 & $0 \%$ \\
\hline R5 & 10 & 18 & $55.55 \%$ & 1 & 18 & $5.55 \%$ \\
\hline TR & 1 & 18 & $5.55 \%$ & 9 & 18 & $50 \%$ \\
\hline
\end{tabular}

Table 8. Percentage of Many Students in Each Indicator of Students' Mathematical Literacy Posttest Number 4 (Level 3)

\begin{tabular}{|c|c|c|c|c|c|c|}
\hline \multirow{2}{*}{$\begin{array}{l}\text { Mathematical } \\
\text { Literacy } \\
\text { Ability }\end{array}$} & \multicolumn{3}{|c|}{ Tipe A } & \multicolumn{3}{|c|}{ Tipe B } \\
\hline & A & $n_{A}$ & $\mathrm{P}$ & A & $n_{B}$ & $\mathrm{P}$ \\
\hline R1 & 4 & 18 & $22.22 \%$ & 1 & 16 & $6.25 \%$ \\
\hline $\mathrm{R} 2$ & 1 & 18 & $5.55 \%$ & 3 & 16 & $18.75 \%$ \\
\hline R3 & 5 & 18 & $27.22 \%$ & 2 & 16 & $12.50 \%$ \\
\hline $\mathrm{R} 4$ & 1 & 18 & $5.55 \%$ & 8 & 16 & $50 \%$ \\
\hline R5 & 1 & 18 & $5.55 \%$ & 2 & 16 & $12.50 \%$ \\
\hline TR & 6 & 18 & $33.33 \%$ & 0 & 16 & $0 \%$ \\
\hline
\end{tabular}

Explanation of Students' Mathematical Literacy in Solving PISA test Level 2 and Level 3:

A: Number of students in group R1, R2, R3, R4, R5, or TR

$\mathrm{n}$ : Total number of students who take pretest or posttest in group R1, R2, R3, R4, $\mathrm{R} 5$, or TR

P: Percentage of students in group R1, R2, R3, R4, R5, or TR

$\mathrm{n}_{\mathrm{A}}$ : Total number of students who take posttest type A in group R1, R2, R3, R4, R5, or TR

$\mathrm{n}_{\mathrm{B}}$ : Total number of students who take posttest type B in group R1, R2, R3, R4, R5, or TR

R1: Students are able to provide answers and appropriate steps

R2: Students are able to provide the correct answer but there are steps that less appropriate.

R3: Students are not able to provide the correct answer but there are most appropriate steps.

R4: Students are able to provide the correct answer but most misstep.

R5: Students are not able to provide the correct answer and only there is a small portion in appropriate steps. 
TR: Students are not able to provide the correct answer and use wrong steps or no answer.

Below are the examples of student's solving of pretests:

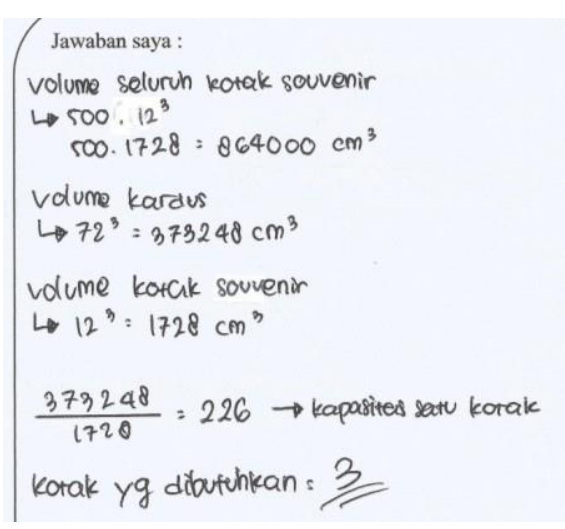

Image 1. Sample student's solving that belongs to R1

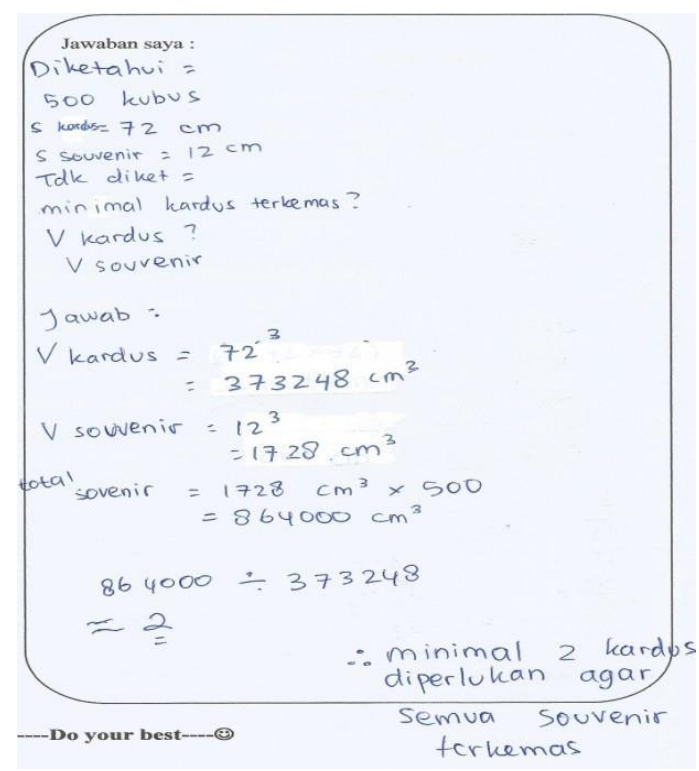

Image 2. Sample student's solving that belongs to R3 


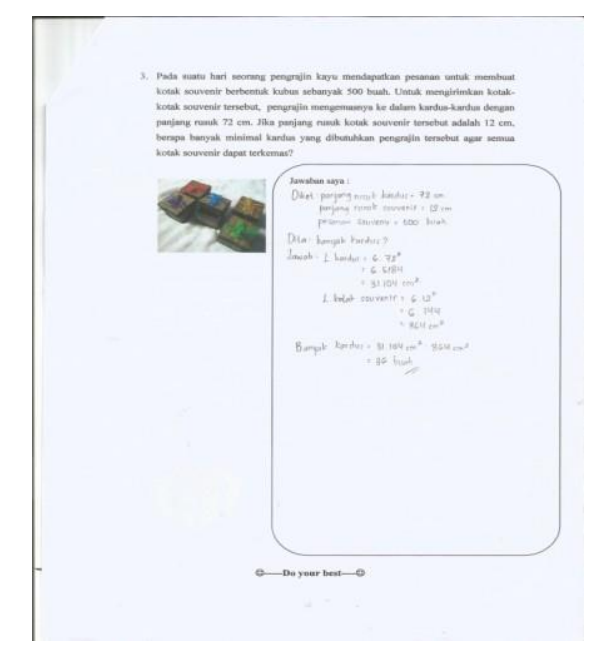

Image 3. Sample student's solving that belongs to TR

A students' mathematical literacy in solving question level 2 in pretest was good. The students were able to sort information from main sources. Furthermore, most of the students were also able to use the formula and complete the basic algorithm shown by most of the students was able to determine the exact volume of the cuboid. Students' mistakes that they did were technical mistakes, such as mistakes of writing unit, misconceptions about mathematical terms, and miscalculation. $66.65 \%$ of students were able to solve pretest level 2 well with most of the right steps. The students' ability of literacy in solving mathematical level 3 in pretest was poor. As many as $38 \%$ of students can solve problems with proper steps while most of them did mistakes conceptually. Other mistakes were mistakes in the calculation and inability of students to draw conclusions from the final answer that is obtained.

Students' mathematical literacy in solving question level 2 in posttest can be said to poor. $57 \%$ of students were not able to solve the questions well and using inappropriate steps. This is possibly due to a lack of preparation of students in doing posttest, the limitation of time in doing the test in which the same time (80 minutes), the amount of posttest more, and posttest requires understanding concept more deeply. In addition, in learning using PMRI approach, the teacher more focused on constructing students' mathematical knowledge instead of doing exercises and discussion about PISA problems. Students' mathematical literacy in solving posttest level 3 is better when compared to the students' literacy ability in solving mathematical pretest. This may be because teachers use problems are not accustomed pretest students met so that students are not accustomed to think contextually. Furthermore, in mathematics learning using PMRI approach, the teacher gives question or problem as a context and tool to train the students to use model (which previously had constructed their own) is resolving the problem. In addition, steps to resolve the posttest less when compared with the pretest, it is just that the level of difficulty to identify a resolution is more complicated and requires a deeper understanding of the concept. The steps that are not so long and 
habits of students in solving level 3 during learning makes students' mathematical literacy in solving better posttest than pretest when solving problems.

\section{Conclusion}

Based on the analysis and discussion about profile of students' mathematical literacy grade VIII F SMP Pangudi Luhur 1 Yogyakarta in learning using the PMRI approach on the subject of cube and cuboid, it can be concluded as follows: a. Pretest: Students' mathematical literacy in solving level 2 was good enough. In contrast, students' mathematical literacy of level 3 was poor and b. Posttest: Students' mathematical literacy in solving level 2 was poor. It is caused to concept and technical errors, most likely also caused by learning that was done more focus on understanding concept and less focus on exercises, so the students are still less skilled in solving contextual problems. In addition, students' mathematical literacy in level 3 was better.

Based on the conclusions and limitation of the research, suggestions that can be given by the researcher are as follows. First, Mathematics teachers can use PMRI approach routinely to discover and train the students' mathematical literacyin order to further develop so that students are more creative in solving problems. Second, future researchers should take into account and prepare the time to do an interview, so researchers can confirm and explore students' completion strategy. Furthermore, the results of the interview compared with the results of pretest and posttest, so students' mathematical literacy data can be reasonably well described.

\section{References}

Gravemeijer, K.P.E. (1997). Developing realistic mathematics education. Utrech: Freudenthal Institute.

Kusumah, Y. S. (2010). Literasi matemakas. Papers submitted in National Seminar JPMIPA FKIP University of Lampung on November $26^{\text {th }}$ 2011. Prosiding ISBN : 978-979-8510-32-8.

Marpaung, Y. \& Julie, H. (2011). PMRI dan PISA: Suatu usaha peningkatan mutu pendidikan matematika di Indonesia. Widya Dharma.

Moleong, L. J. (2007). Metodologi penelitian kualitatif. Bandung: PT Remaja Rosdakarya.

National Council of Teacher Mathematics. (2000). Principles and standard for school mathematics. Reston: The Natinal Council of Teachers of Mathematics, Inc.

OECD. (2003). Literacy skills for the world of tomorrow: Further results from PISA 2000. Paris: OECD

OECD. (2010). PISA 2009 Results: What Students Know and Can Do. Student performance in reading, mathematics, and science (Vol 1). Paris: OECD.

OECD. (2013). PISA 2012 assessment and analytical framework: Mathematics, reading, science, problem solving, financial literacy. OECDPublising.

Permendiknas No 22 Years 2006 about Standar Isi Mata Pelajaran Matematika.

Robert S., Hoogland K., \& Dolk M. (2010). A decade of PMRI in Indonesia. Bandung. 
IJIET Vol. 1, No. 1, January 2017

Santika, et al. (2012). Pembelajaran matematika realistik Indonesia dengan asesmen bernuansa PISA untuk kemampuan pemecahan masalah siswa SMP. Paper of State University of Semarang. accessed from: portalgaruda.org/article.php. Accesed on Februari $27^{\text {th }} 2016$.

Sukardi. (2003). Metodologi penelitian pendidikan. Yogyakarta: Bumi Aksara.

Sukmadinata, N. S. (2012). Metodologi penelitian pendidikan. Bandung: PT Remaja Rosdakarya.

Suryanto, et al. (2010). Sejarah Pendidikan Matematika Realistik Indonesia PMRI).

The Guardian. 2013. PISA 2012 results: Which country does best at reading maths and science? www.theguardian.com/news/datablog/2013/dec/03/pisaresults-country-best-reading-maths-science. Accessed on February 27, 2016.

Undang-undang Republik Indonesia No. 20 Tahun 2003.

Van den Heuvel-Panhuizen, M. (1998). Realistic mathematics education. Work in progress. Accessed from: http://www.fi.uu.nl/en/rme

Wijaya, A. (2012). Pendidikan matematika realistik: Suatu alternatif pendekatan pembelajaran matematika. Yogyakarta: Graha Ilmu.

www.litbang,.kemendikbud.go.id/indeks.php/survei.internasional.pisa Accessed on February 27, 2016. 